\title{
NEW DISTRIBUTIONAL RECORD OF TWELVE SCLERACTINIAN CORALS FROM SAINT MARTIN'S ISLAND, BANGLADESH
}

\author{
Kazi Ahsan Habib* and Md. Jayedul Islam ${ }^{1}$ \\ Department of Fisheries Biology and Genetics, Faculty of Fisheries, Aquaculture \\ and Marine Science, Sher-e-Bangla Agricultural University, Dhaka 1207, \\ Bangladesh
}

\begin{abstract}
Saint Martin's Island is the only island in Bangladesh where coral communities are found. An expedition on marine biodiversity monitoring of Saint Martin's Island through underwater visual census method was carried out from December 2017 to March 2018. In this study, a total of 25 scleractinian coral species of 8 families and 14 genera were identified, of which 12 species, Dipsastraea lizardensis, Dipsastraea maritima, Dipsastraea veroni, Favites acuticollis, Favites melicerum, Favites pentagona, Goniastrea stelligera, Goniopora albiconus, Goniopora norfolkensis, Pavona clavus, Plesiastrea versipora, and Psammocora exesa were recorded for the first time in Bangladeshi marine water. These new records exemplify gaps in sampling and recording of coral species in Bangladesh, and suggest the need of extensive research on coral ecosystem in the country. Assessment of different valid reports and publications including the present study revealed that a total of 98 species of hard corals of 18 families and 37 genera have been reported until now in Saint Martin's Island as well as Bangladesh.
\end{abstract}

Key words: The Bay of Bengal, Hard Coral, First Report, Saint Martin's Island.

\section{INTRODUCTION}

The anthozoan order Scleractinia (Cnidaria: Anthozoa) are known as stony corals or hard corals and are well recognized as reef-building corals due to their solid, massive and encrusting mode of structural conformation. They are formed along the continental shelf of the seas as the pattern of barrier, fringing and atoll mode habituation, and widely distributed in the Indo-Pacific region (Veron 1995). The taxonomy of hard corals has been extensively studied worldwide. However, coral diversity of the Northern Indian Ocean is poorly known. Although there are some studies on reef-building coral diversity in the northern Indian Ocean (NIO), those were particularly conducted in its western part including the

\footnotetext{
*Author for correspondence: <ahsan.sau@gmail.com>, 1Aquatic Bioresource Research Lab (ABR Lab.), Department of Fisheries Biology and Genetics, Faculty of Fisheries, Aquaculture and Marine Science, Sher-e-Bangla Agricultural University, Dhaka 1207, Bangladesh

○2021 Zoological Society of Bangladesh DOI: https://doi.org/10.3329/bjz.v49i1.53678
} 
Red Sea and Arabian Sea (Obura 2016). However, the coral diversity in the Eastern part of NIO i.e., in the northern Bay of Bengal is poorly known globally.

In the maritime area of Bangladesh, the coral communities are only found in the Saint (St.) Martin's Island, a small island with an area of about $12 \mathrm{sq.} \mathrm{km}$ (Thompson and Islam 2010) in the northeast part of the Bay of Bengal. Almost the entire coastline of St. Martin's Island is fringed by a unique rocky intertidal and its width varies from 100 to $400 \mathrm{~m}$ at spring low tides, and the island is marginal for the development and survival of coral communities (Tomascik 1997). Rocky reefs are the main component to build the reef ecosystem of this island. Although coral reefs are not present in this island, yet they do support relatively diverse zooxanthellate/hermatypic coral communities, and coral reefassociated fauna and flora (Tomascik 1997). Coral communities in the St. Martin's Island are found around most of its area and extend to about 200 to $600 \mathrm{~m}$ offshore, but their abundance is generally low covering from $7.3 \%$ to $8.8 \%$ (Mollah 1997, Tomascik 1997, Thompson and Islam 2010).

Most of the study on St. Martin's Island was focused on the impact of anthropogenic and climatic factors on coral habitat of this island (Khan 1985, Hossain et al. 2006, Hossain et al. 2007, Alam et al. 2015, Ahammed et al. 2016, Gazi et al. 2020). However, there is no in-depth study on coral species diversity of the St. Martin's Island except the study of Tomascik (1997) where a total of 65 species were identified. Afterward, few more studies were conducted sporadically by some researchers. In this study, we have identified 12 species of scleractinian corals for the first time in Bangladeshi water through underwater survey.

\section{MATERIAL AND METHODS}

An inventory of the undiscovered coral organisms of St. martin`s Island was made during an expedition on underwater biodiversity monitoring from December 2017 to March 2018 by Aquatic Bio-resource Research Lab. (ABR Lab.), Department of Fisheries Biology and Genetics, Sher-e-Bangla Agricultural University, Dhaka. The surveys were conducted at four sites of Saint Martin's Island viz., Site 1: Ferry Ghat $\left(20^{\circ} 37^{\prime} 56.4^{\prime \prime} \mathrm{N}, 92^{\circ} 19^{\prime} 46.6^{\prime \prime E}\right)$, Site 2: Infront of

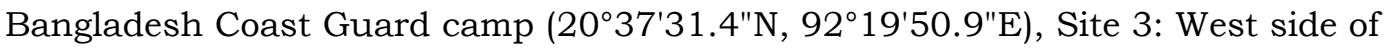
Chera Dwip (20 35'23.99"N, 92 $\left.20^{\circ} 20.06 " \mathrm{E}\right)$ and Site 4: East side of Chera Dwip $\left(20^{\circ} 34^{\prime} 52.3^{\prime \prime} \mathrm{N}, 92^{\circ} 20^{\prime} 29.8^{\prime \prime} \mathrm{E}\right)$. The surveys were conducted using underwater survey methods followed by DeVantier et al. (2000), Donnelly et al. (2003), and Hill \& Wilkinson (2004). The sites were accessed by medium sized patrol fiberboats. At each site, the coral communities and colonies were surveyed using SCUBA by meandering swim where the reef slope fall away to 3-10 $\mathrm{m}$. The depth ranges were selected based on the primary investigation surveys conducted at 
the beginning of the present study and previous study of Tomascik (1997). Each swim was of about 40-80 minutes' duration in each depth range and $70-100 \mathrm{~m}$ around the study site.

St. Martin Island is the only islet in Bangladesh where coral colonies are found and the island is located at the southernmost tip of Bangladesh in the northern Bay of Bengal (Coordinates: 20 $34^{\prime}-20^{\circ} 39^{\prime} \mathrm{N}$ and $92^{\circ} 18^{\prime}-92^{\circ} 21^{\prime} \mathrm{E}$ ) separated from the mainland by a channel of about $9 \mathrm{~km}$ wide (Figure 1). The observed coral species were identified based on the morphological features from the taken photographs (Figure 2, 3, 4 and 5) following Veron (2000), Veron et al. (2020), and Dai and Horng (2009a, 2009b). We have used the recent valid species name according to Worms Editorial Board 2020. The photographs are deposited in the Aquatic Bio-resource Research Lab.

\section{RESULTS AND DISCUSSION}

In the present study, we observed and identified a total of 25 scleractinian coral species of eight families and 14 genera. Among these, 12 species, Dipsastraea lizardensis, Dipsastraea maritima, Dipsastraea veroni, Favites acuticollis, Favites melicerum, Favites pentagona, Goniastrea stelligera, Goniopora albiconus, Goniopora norfolkensis, Pavona clavus, Plesiastrea versipora, and Psammocora exesa were first time recorded in Bangladeshi marine water (Figure 2, 3, 4 and 5). Taxonomic account of these 12 new records is given hereunder:

Family: Agariciidae Gray, 1847

Genus: Pavona Lamarck, 1801

Pavona clavus Dana, 1846

(Cactus Coral)

(Fig. 2a, b)

Pavona clavus Dana, 1846. Veron 2000. Coral of the World. Vol. 2, 198-199.

Characters: The species have massive distinctive colonies with numerous clubs shaped or cylindrical, stout columns. Columns divided but not fuse. Corallites are well-defined and thick walls. Septo-costae are thick, straight and arranged in two very distinct orders. Uniform pale green.

Distribution: They are widely distributed throughout the indo-pacific, from Red Sea, Madagascar to Marshal Island and Fiji, also recorded from Hawaii, the Galapagos of east coast and the Great Barrier Reef (Dai and Horng 2009a, Veron 2000, Veron et al. 2020). They are occurred commonly 
in shallow reefs with strong currents (Veron 2000). This study confirms the presence of this species in Bangladesh waters.

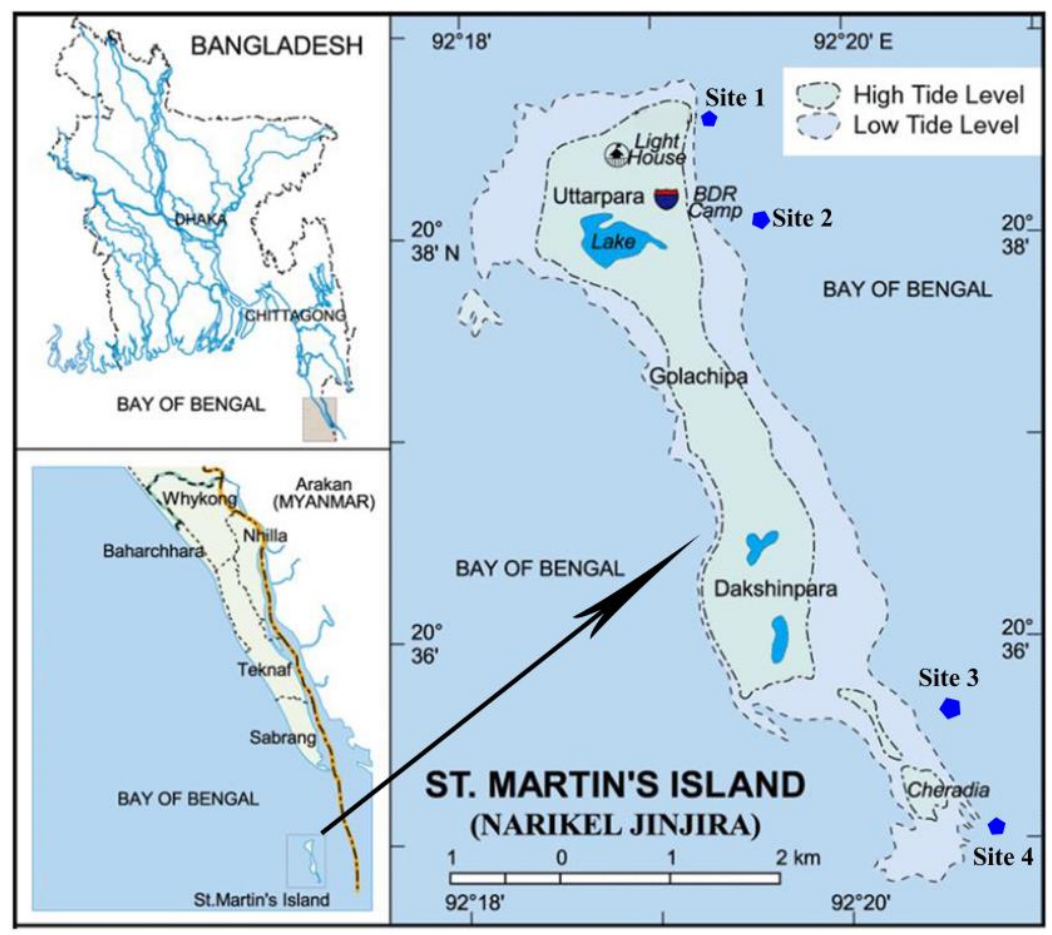

Fig. 1. Location map of four study sites $(\square)$ around St. Martin's Island in Bangladesh (map adopted and modified from Thompson and Islam 2010).

Family: Coscinaraeidae Benzoni, Arrigoni, Stefani \& Stolarski, 2012

Genus: Psammocora Dana, 1846

Psammocora exesa (Dana, 1846)

(Wrinkle Coral)

(Fig. 2c, d)

Psammocora exesa (Dana, 1846). Veron 2000. Coral of the World. Vol. 2, 162163.

Synonym: Coscinaraea exesa (Dana, 1846).

Characters: The species have columnar colonies with a flat top. Corallites are in shallow valleys. Granulated septo-costae. Tentacles are often extended during the day. Uniform dark brown in color.

Distribution: They are widely distributed throughout the Pacific, from the Indonesian archipelago to French Polynesia (Dai and Horng 2009b, Veron 2000, 
Veron et al. 2020). Generally, occurs in shallow reef environments, colonies may reach in several meters in diameter in lagoons (Dai and Horng 2009b, Veron et al. 2020). This study confirms the presence of this species in Bangladesh waters.

Family: Merulinidae Verrill, 1865

Genus: Dipsastraea Blainville, 1830

Dipsastraea lizardensis (Veron, Pichon \& Wijsman-Best, 1977)

(Moon Coral)

(Fig. 2e, f)

Dipsastraea lizardensis (Veron, Pichon \& Wijsman-Best, 1977). Veron 2000. Corals of the world. Vol. 3, 120

Synonym: Favia lizardensis Veron, Pichon \& Wijsman-Best, 1977

Characters: The species have massive colonies. Circular and regularly spaced corallites. Thick corallite walls. Widely spaced and thin septa; paliform lobes absent. Costae are well developed. Pinkish brown with cream in color.

Distribution: They are widely distributed in the tropical and subtropical areas where shallow reef environments present (Veron 2000, Veron et al. 2020, Palomares and Pauly 2020). They are occurred in upper reef slopes (Veron 2000). This study confirms the presence of this species in Bangladesh waters.

Dipsastraea maritima (Nemenzo, 1971)

(Honeycomb Coral)

(Fig. 3a, b)

Dipsastraea maritima (Nemenzo, 1971). Veron 2000. Corals of the world. Vol. 3, 130.

Synonym: Favia maritima (Nemenzo, 1971)

Characters: The species have massive colonies; semicircular exsert corallites. Numerous fine septa present. Paliform lobes poorly developed. Dark brown in color.

Distribution: They are widely distributed in the tropical and subtropical areas where shallow reef environments present (Veron 2000, Veron et al. 2020, Palomares and Pauly 2020). Generally, they occur in reef slopes (Veron 2000). This study confirms the presence of this species in Bangladesh waters.

Dipsastraea veroni (Moll \& Best, 1984)

(Knob coral)

(Fig. 3c, d) 
Dipsastraea veroni (Moll \& Best, 1984). Veron 2000. Corals of the world. Vol. 3, 128-129.

Synonym: Favia veroni Moll \& Best, 1984

Characters: The species have massive colonies. Corallites are compressed together, often irregularly projecting and irregular in outline. Paliform lobes are absent. Corallite walls are brown in color and oral discs light green in color.

Distribution: They are widely distributed in the tropical and subtropical areas where coral environments present (Veron 2000, Veron et al. 2020, Palomares and Pauly 2020). Generally, they are occurred in reef slopes (Veron 2000). This study confirms the presence of this species in Bangladesh waters.

Genus: Favites Link, 1807

Favites acuticollis (Ortmann, 1889)

(Pineapple coral)

(Fig. 3e, f)

Favites acuticollis (Ortmann, 1889). Veron 2000. Corals of the world. Vol. 3, 141. Synonym: Prionastraea acuticollis Ortmann, 1889

Characters: The species have submassive to encrusting colony. Deep corallites have thin angular walls. Few widely spaced septa present, paliform lobes are absent. Dark brown in colors, often with white upper margins to walls.

Distribution: They are widely distributed in the tropical and subtropical areas where shallow reef environments present (Veron 2000, Veron et al. 2020, Palomares and Pauly 2020). This study confirms the presence of this species in Bangladesh waters.

Favites melicerum (Ehrenberg, 1834)

(Pineapple Coral)

(Fig. 4a, b)

Favites melicerum (Ehrenberg, 1834). Veron 2000. Corals of the world. Vol. 3, 140.

Synonym: Favites bestae Veron, 2000

Characters: The species have submissive to encrusting colony. Corallites are rounded with thick walls. Fewer numbers of septa present. Well-developed paliform lobes. Brown in color with contrasting walls and centers.

Distribution: They are widely distributed in the tropical and subtropical areas where shallow reef environments present (Veron 2000, Veron et al. 2020, Palomares and Pauly 2020). This study confirms the presence of this species in Bangladesh waters. 


\section{Favites pentagona (Esper, 1795)}

(War coral)

(Fig.4c, d)

Favites pentagona (Esper, 1795). Veron 2000. Corals of the world. Vol. 3, 138139.

Characters: The species have submassive to encrusting colony, sometimes forming irregular columns. Corallites angular with thin wall. Septa are few in number. Well-developed paliform lobes forming a conspicuous crown. Brightly brown in color with green oral discs.

Distribution: They are widely distributed in the tropical and subtropical areas where shallow reef environments found (Veron 2000, Veron et al. 2020, Palomares and Pauly 2020). This study confirms the presence of this species in Bangladesh waters.

Genus: Goniastrea Milne Edwards \& Haime, 1848

Goniastrea stelligera (Dana, 1846)

(Knob coral)

(Fig. 4e, f)

Goniastrea stelligera (Dana, 1846). Veron 2000. Corals of the world. Vol. 3, 102103.

Synonym: Favia stelligera var. fanningensis Vaughan, 1918

Characters: The species have a spherical, columnar flat colony and maybe several meters across. Corallites are conical with thick walls and small openings. Costae well developed and equal. Uniform green in color.

Distribution: They are widely distributed in the tropical and subtropical areas where shallow reef environments present (e.g. Indo-Pacific: the Red Sea and eastern Africa, east to Easter Island, north to the Ryukyu Islands, south to New Caledonia) (Veron 2000, Veron et al. 2020, Palomares and Pauly 2020). This study confirms the presence of this species in Bangladesh waters.

Family: Plesiastreidae Dai \& Horng, 2009

Genus: Plesiastrea Milne Edwards \& Haime, 1848

Plesiastrea versipora (Lamarck, 1816)

(Small knob coral)

(Fig. 5a, b)

Plesiastrea versipora (Lamarck, 1816). Veron (2000). Corals of the world. Vol. 3, 226-227. 


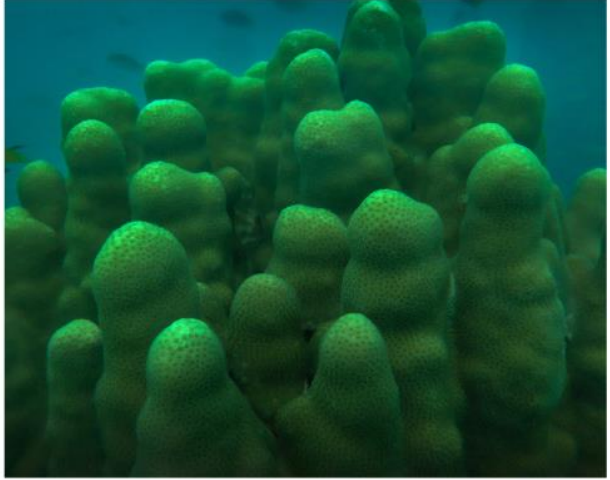

2a

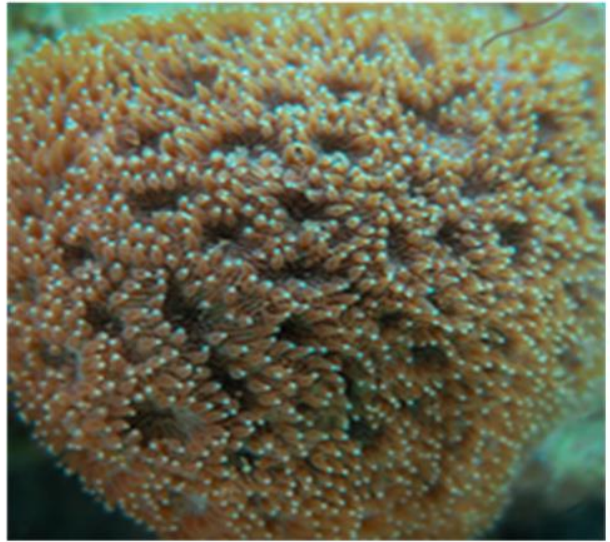

2c

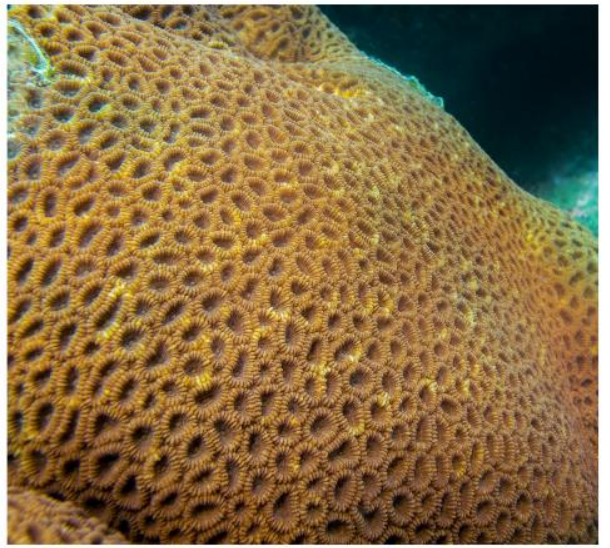

$2 \mathrm{e}$

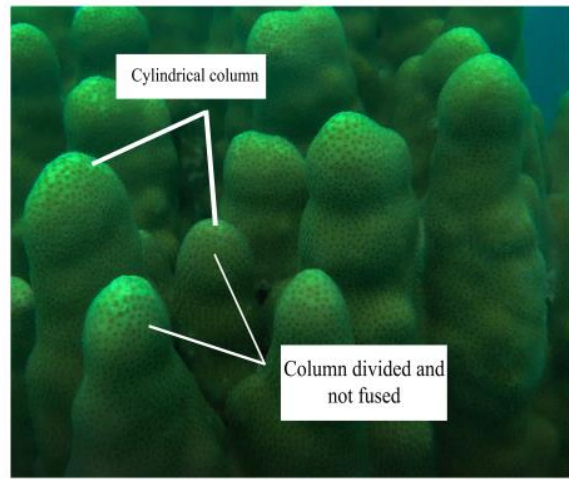

2b

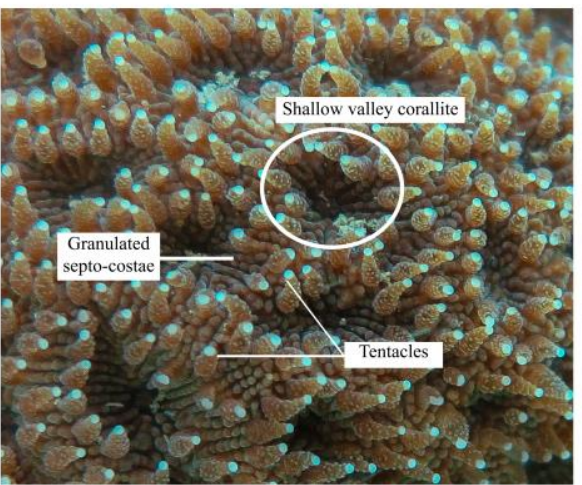

2d

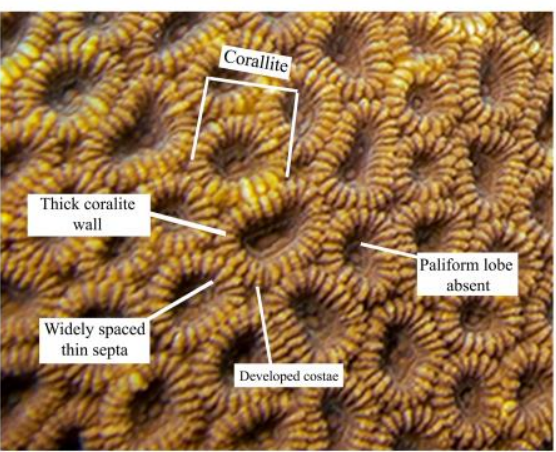

$2 \mathbf{f}$

Fig. 2. Photographs showing the species with key identifying characters of the hard coral: Pavona clavus (2a \& 2b); Psammocora exesa (2c \& 2d) and Dipsastraea lizardensis (2e \& 2f). 
Characters: The species have a flat and frequently lobed colony. Small Corallites. Paliform lobes form a neat circle around small columellae. Tentacles short and are of two alternating sizes, sometimes extended during the day. Green in color.

Distribution: They are widely distributed in the tropical and subtropical areas where coral environments present (Indo-Pacific: Japan to Australia and South Africa to Easter Island) (Veron 2000, Veron et al. 2020, Palomares and Pauly 2020). They are occurred in most reef environments but especially in shaded places and also occurred in rocky tidemarks of temperate places protected from strong wave action (Veron 2000, Veron et al. 2020). This study confirms the presence of this species in Bangladesh waters.

Family: Poritidae Gray, 1840

Genus: Goniopora de Blainville, 1830

Goniopora albiconus Veron, 2000

(Anemone coral)

(Fig. 5c, d)

Goniopora albiconus Veron, 2000. Veron 2000. Corals of the world. Vol. 3, 361.

Characters: The species have an encrusting colony, forming thin irregular laminae. Corallites are shallow polygonal with thin walls. Irregularly fused septa; small columellae; Exceptionally large oral cones while tentacles are short and thin. Oral cones are white in color and conspicuous.

Distribution: They are widely distributed in the tropical and subtropical areas where shallow reef environments present (Veron 2000, Veron et al. 2020, Palomares and Pauly 2020). This study confirms the presence of this species in Bangladesh waters.

\section{Goniopora norfolkensis Veron \& Pichon, 1982}

(Anemone coral)

(Fig. 5e, f)

Goniopora norfolkensis Veron \& Pichon, 1982. Veron 2000. Corals of the world. Vol. 3, 362-363.

Characters: The species have hemispherical to submissive colony. Septa steeply plunging. Paliform lobes absent. Polyps white in color; distinctively colored oral discs. Polyps with long shaggy tentacles.

Distribution: They are widely distributed in the tropical and subtropical areas where shallow reef environments present (Veron 2000, Veron et al. 2020, Palomares and Pauly 2020). This study confirms the presence of this species in Bangladesh waters. 


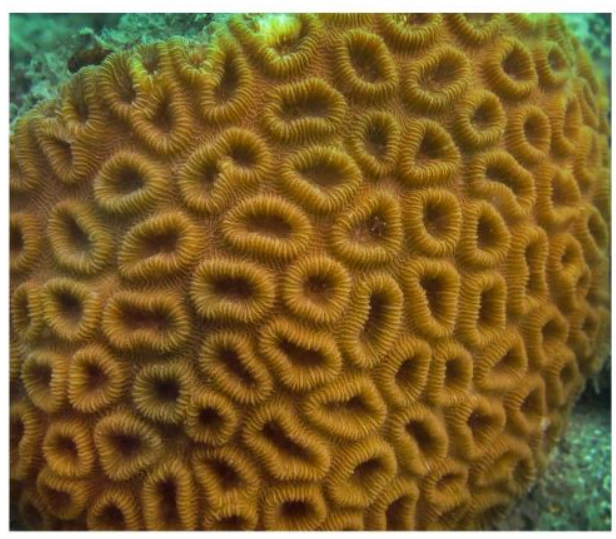

3a

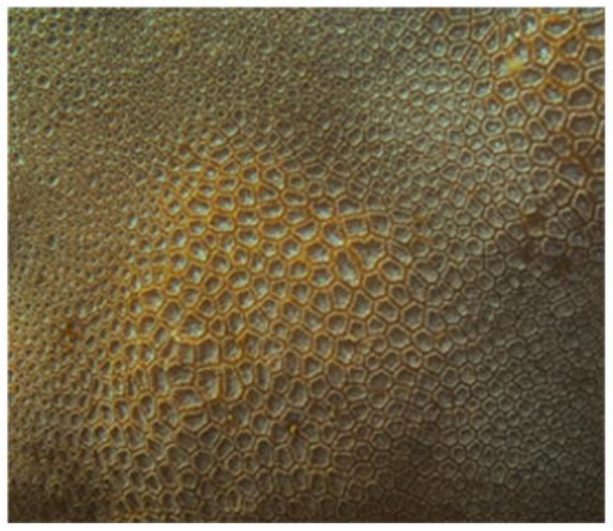

$3 c$

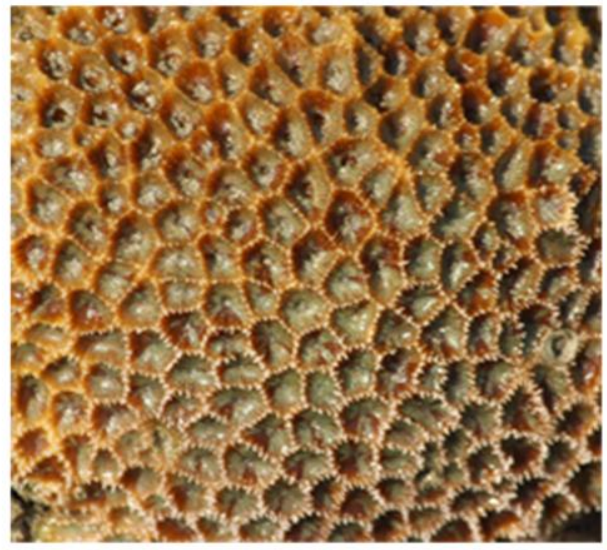

$3 e$

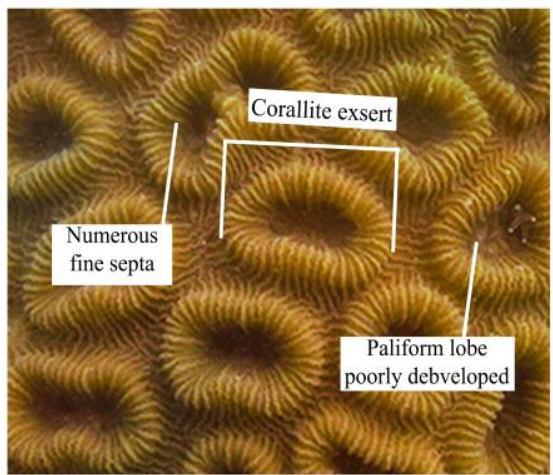

3b

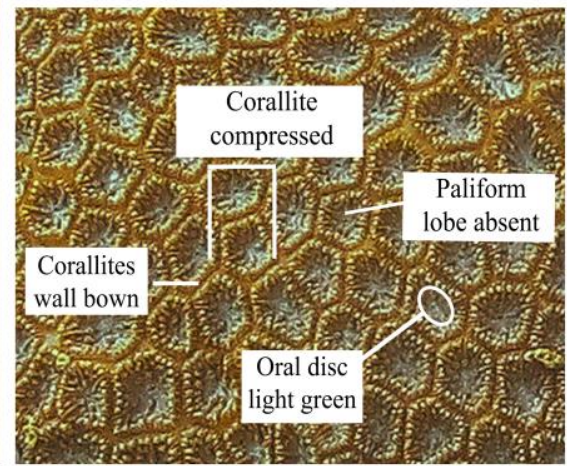

3d

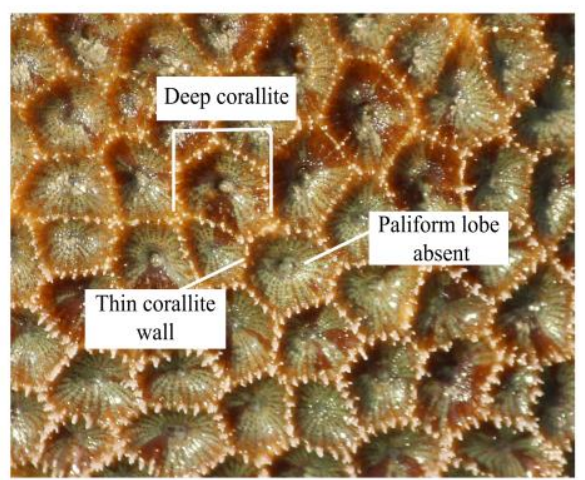

3f

Fig. 3. Photographs showing the species and key identifying characters of hard coral: Dipsastraea maritima (3a \& 3b); Dipsastraea veroni (3c \& 3d) and Favites acuticollis (3e \& 3f). 


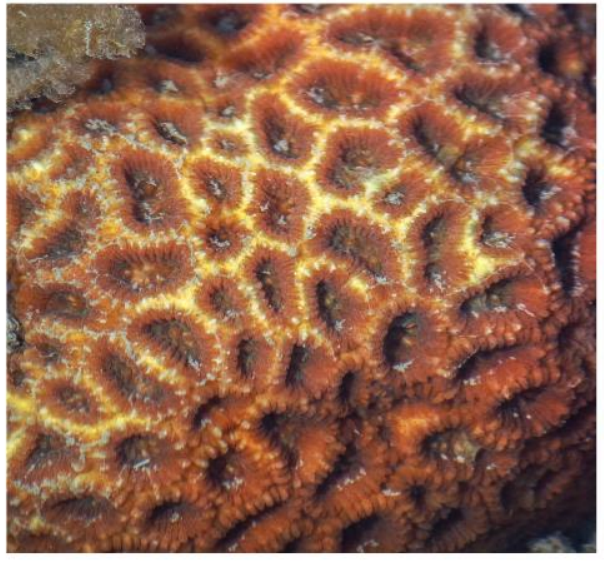

$4 a$

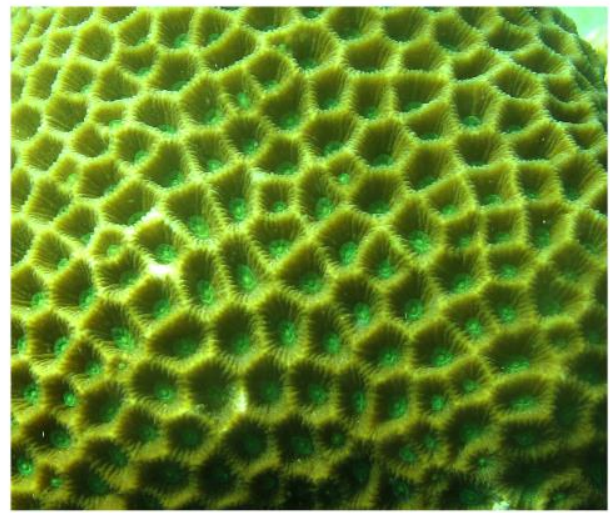

$4 \mathrm{c}$

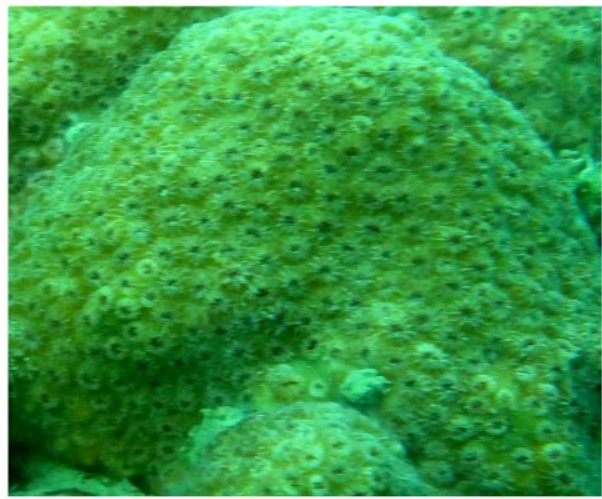

$4 e$

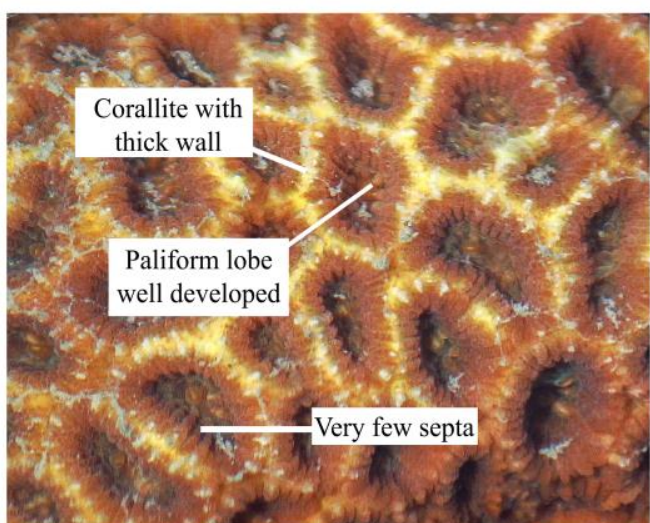

$4 b$

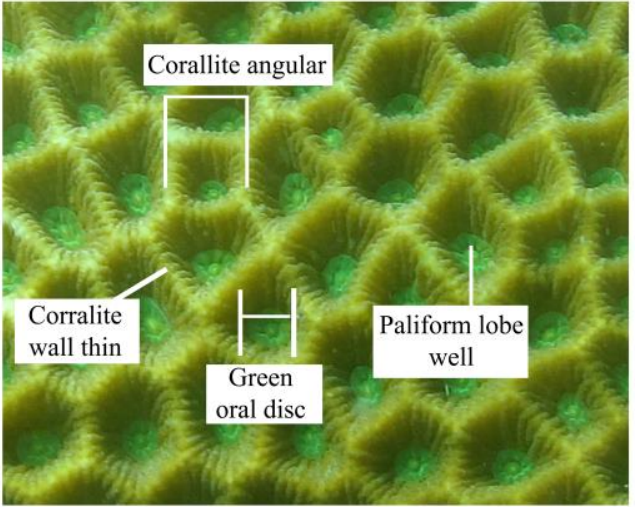

4d

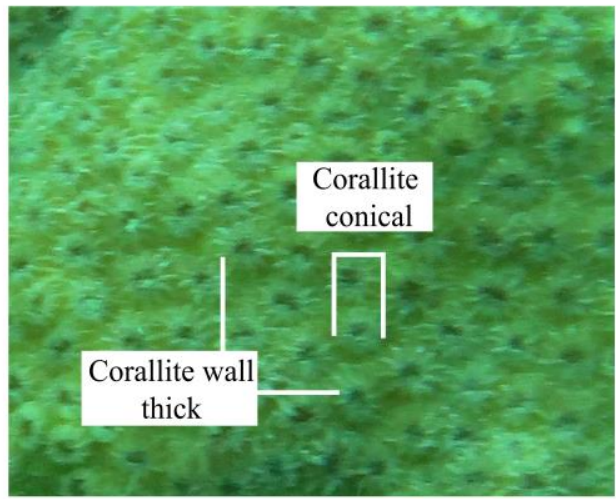

4f

Fig. 4. Photographs showing the species and key identifying characters of hard coral: Favites melicerum (4a \& 4b); Favites pentagona (4c \& 4d) and Goniastrea stelligera (4e \& 4f). 


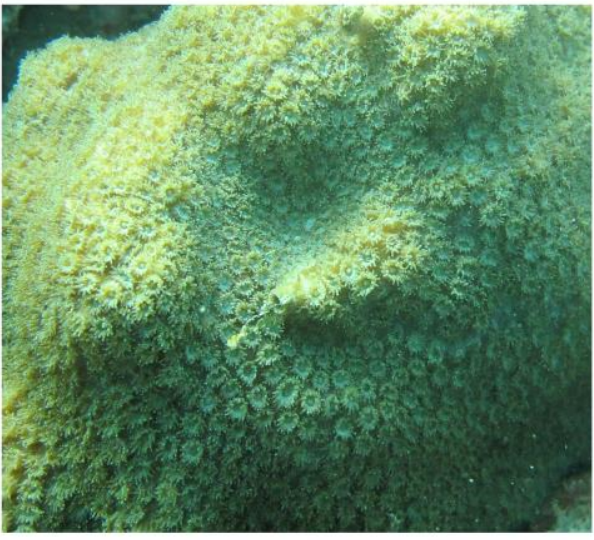

5a

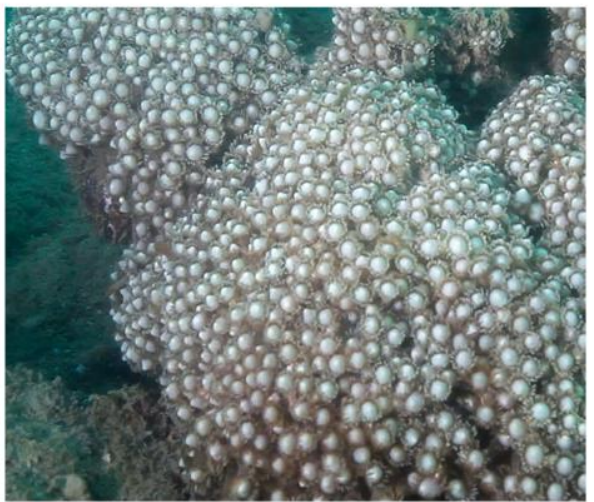

$5 \mathbf{c}$

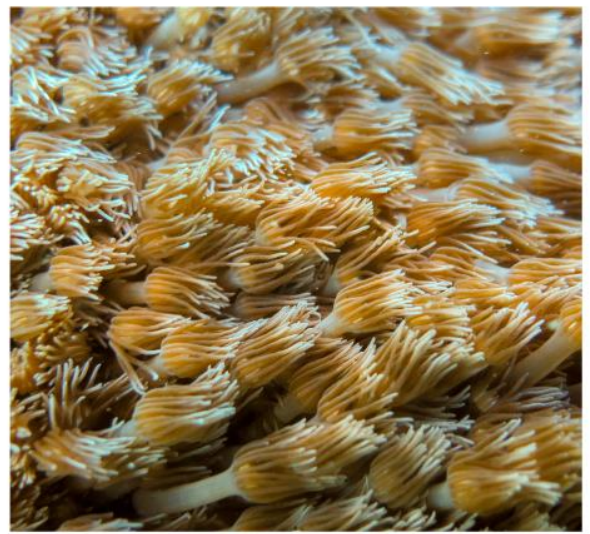

$5 \mathbf{e}$

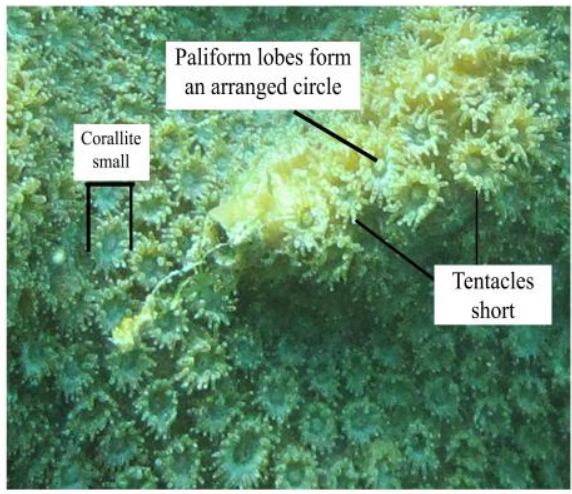

$5 \mathbf{b}$

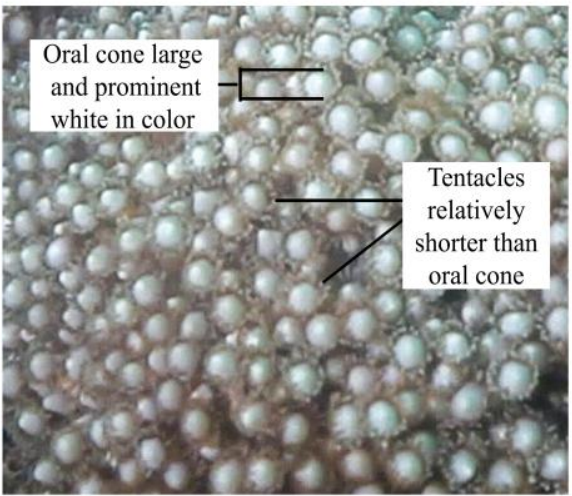

5d

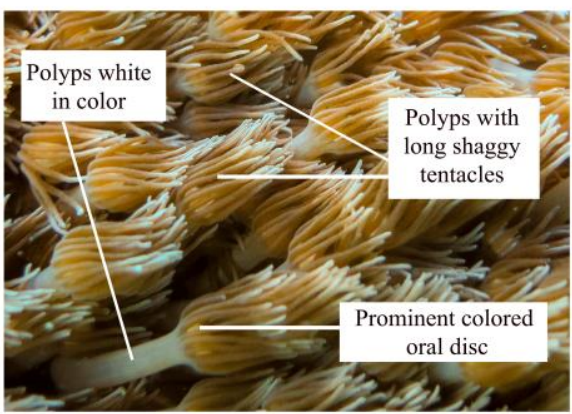

5f

Fig. 5. Photographs showing the species and key identifying characters of hard coral: Plesiastrea versipora ( $5 \mathrm{a} \& 5 \mathrm{~b})$; Goniopora albiconus ( $5 \mathrm{c} \& 5 \mathrm{~d}$ ) and Goniopora norfolkensis (5e \& 5f).

The Saint Martin's Island is the only island in Bangladesh where coral communities and coral reef like ecosystem are found. There are 65 species of 
hard coral listed from Bangladesh. Tomascik (1997) mentioned that the coral community is relatively diverse in contrast of the environmental setting of the Saint Martin's Island. No significant study was conducted to assess the species diversity of the coral in Bangladesh after the survey of Tomascik (1997).

Present survey was conducted to assess the present status of species diversity of Scleractinian coral of Saint Martin's Island with underwater observation through scuba diving. However, the survey period of only 4 months along with limited survey area were not enough to make a conclusive inventory of corals. In our survey, we have identified 25 species of hard corals where 12 species were the new addition in the country's coral inventory. We have reviewed different valid reports and publications (i.e., Mollah 1997, Tomascik 1997, Kabir et al. 2008, BOBLME 2015, Ahammed et al. 2016, Hasan 2009, Gazi et al. 2020) including the present study to make a depiction about species diversity in St. Martin's Island as well as Bangladesh which revealed that a total of 98 species of hard corals of 18 families and 37 genera have been reported in the country until now. Discovery of new records within a short period of survey in our study indicates that more species could be present in the St. Martin's Island. Therefore, in-depth study on coral ecosystem and associated species diversity of the St. Martin's Island is needed to make a proper management plan to protect this resourceful island.

Coral ecosystems are great in danger throughout the world because of different anthropogenic and natural factors such as climate change, overfishing, marine pollution, unplanned tourism, plastic pollution, etc. (Hall-Spencer et al. 2002, Bruno and Selig 2007, Obura et al. 2008, Burke et al. 2011, Hughes et al. 2011). Likewise, the biodiversity as well as coral fauna of St. Martin Island has also been decreased over last few decades. A total area of $0.9342 \mathrm{sq} . \mathrm{km}$ of coral colonies disappeared from 1980 to 2018 and anthropogenic factors are affecting more for coral degradation of St. Martin's Island than the natural factors (Gazi et al. 2020). Unplanned tourism, extraction and selling of coral stones for showcasing, coastal erosion, damaging due to boat anchoring, sedimentation, entangled and covering of coral surfaces by ghost nets, oil spillage from boats and motels, plastic pollutions etc. were identified as the anthropogenic factors causing coral degradation and hampering the natural processes in the island (Mollah 1997, Tomascik 1997, Rajasuriya et al. 2002, Thompson and Islam 2010, Ahammed et al. 2016, Gazi et al. 2020). St. Martin's Island was declared an Ecologically Critical Area in 1999 under Bangladesh Environmental Conservation Act. It is urgently needed to delineate the ecosystem boundary of St. Martin's Island and properly assess the present status of biodiversity within this area. Based on these findings along with relevant surveys, it is needed to 
immediately declare the island as marine protected area (MPA) to protect this natural treasure of Bangladesh.

Acknowledgements: This study was supported by UNESCO/Korean Fundsin-Trust funded DRMREEF project managed by IOC Sub-Commission for the Western Pacific (WESTPAC). We would like to thank Prof. Suharsono (Research Center for Oceanography, Indonesian Institute of Sciences) for his valuable comments on species identification. We acknowledge to Mr. Sufi Md. Atiqur Rahman and Md. Sharif Sarwar for their assistance in Scuba Diving.

\section{LITERATURE CITED}

AHAMMED, S.S., HOSSAIN, M.A., ABEDIN, M.Z. and KHALEQUE, M.A. 2016. A study of environmental impacts on the coral resources in the vicinity of the Saint Martin Island, Bangladesh. International Journal of Scientific \& Technology Research, 5(1): 37-39.

ALAM, O., DENG, T.L., UDDIN, M.N. and ALAMGIR, M. 2015. Application of environmental ethics for sustainable development and conservation of Saint Martin's Island in Bangladesh. Journal of Environmental Science and Natural Resources 8(1): 19-27.

BOBLME 2015. Report on Saint Martin's Island ecosystem boundary, Bangladesh. BOBLME-2015Ecology-49: $57 \mathrm{pp}$.

BRUNO, J.F. and SELIG, E.R. 2007. Regional decline of coral cover in the Indo-Pacific: Timing, extent, and sub-regional comparisons. PLoS One 2(8): e711.

BURKE, L., REYTAR, K., SPALDING, M. and PERRY, A. 2011. Reefs at Risk Revisited. World Resources Institute, Washington DC, 104 p.

DAI, C.-F. and HORNG, S. 2009a. Scleractinia fauna of Taiwan I. National Taiwan University, Taiwan.

DAI, C.-F. and HORNG, S. 2009b. Scleractinia fauna of Taiwan II. National Taiwan University, Taiwan.

DEVANTIER, L.M., TURAK, E., AL-SHAIKH, K. and DE'ATH, G. 2000. Coral communities of the central-northern Saudi Arabian Red Sea. Fauna of Arabia, 18: 23-66.

DONNELLY, R.D., NEVILLE and MOUS P.J. (Eds.). 2003. Report on a Rapid Ecological Assessment of the Raja Ampat Islands, Papua, Eastern Indonesia, held October 30 - November 22, 2002, The Nature Conservancy Southeast Asia Center for Marine Protected Areas, Sanur, Bali Indonesia: 249 pp. www.komodonationalpark.org

GAZI, M.Y., MOWSUMI, T.J. and AHMED, M.K. 2020. Detection of Coral Reefs Degradation using Geospatial Techniques around Saint Martin's Island, Bay of Bengal. Ocean Science Journal, 55(3): 419-431.

HABIB, K.A., ISLAM, M.J. and NEOGI, A.K. 2021. Underwater Citizens of Saint Martin's Island, Bangladesh. Sher-e-Bangla Agricultural University, 184 pp. (ISBN: 978-984-35-0571-2)

HALL-SPENCER, J., ALLAIN, V. and FOSSÅ, J.H. 2002. Trawling damage to Northeast Atlantic ancient coral reefs. Proceedings of the Royal Society B: Biological Sciences, 269: 507-511. 
HASAN, M. M. 2009. 'Tourism and Conservation of Biodiversity: A Case Study of St. Martins Island, Bangladesh', (1) Law, Social Justice \& Global Development Journal (LGD). (http://www.go.warwick.ac.uk/elj/lgd/2009_1/ hasan)

HILL, J. and WILKINSON, C. 2004. Methods for ecological monitoring of coral reefs. Version 1. Australian Institute of Marine Science, Townsville, Australia, $117 \mathrm{pp}$.

HOSSAIN M.M. and ISLAM, M.H. 2006. Status of the biodiversity of St. Martin's Island, Bay of Bengal, Bangladesh. Pakistan Journal of Marine Science 15(2): 201-210.

HOSSAIN, M.S., CHOWDHURY, S.R. and RASHED-UN-NABI, M. 2007. Resource Mapping of Saint Martin's Island using satellite image and ground observations. Journal of Forestry Environment, 5: 23-36.

HUGHES, T.P., BELlWOOD, D.R., BAIRD, A.H., BRODIE, J., BRUNO, J.F. and PANDOLFI J.M. 2011. Shifting base lines, declining coral cover, and the erosion of reef resilience: comment on Sweatman et al. 2011. Coral Reefs, 30(3): 653-660.

KABIR, S.M.H., AHMED, M., AHMED, A.T.A., RAHMAN, A.K.A., HAQUE, E.U., AHMED, Z.U., BEGUM, Z.N.T., HASSAN, M.A., and KHONDKER, M. (Eds.). 2008. Encyclopedia of flora and fauna of Bangladesh. Protozoa-Gastrotricha. Asiatic Society of Bangladesh, Dhaka. Vol.14, 335 pp.

KHAN, M.A.R. 1985. Saint Martin's: a vanishing coral island of Bangladesh. Tiger paper (FAO/RAPA), 12(4): 6-12.

MOLLAH A.R. 1997. Status of Coral and Associated Resources in Bangladesh. In: Hoon V. Proceedings of the Regional Workshop on the Conservation and Sustainable Management of Coral Reefs. Proceedings No.22, CRSARD, India. (http://www.fao.org/3/x5627e/x5627e08. htm)

OBURA, D. O. 2016. An Indian Ocean centre of origin revisited: Palaeogene and Neogene influences defining a biogeographic realm. Journal of Biogeography, 43: 229-242.

OBURA, D., TAMELANDER, J. and LINDÉN, O. 2008. Coastal oceans research and development in the Indian Ocean. Department of Biology and Environmental Science, University of Kalmar, Kalmar, 457 pp.

PALOMARES, M.L.D. and PAULY. D. (Eds.). 2020. SeaLifeBase. World Wide Web electronic publication. www.sealifebase.org, version (07/2020) on 20 September 2020.

RAJASURIYA, A., ZAHIR, H., MULEY, E.V., SUBRAMANIAN, B.R., VENKATARAMAN, K., WAFAR, M.V.M. and WHITTINGHAM, E.M.M.A. 2002. Status of coral reefs in South Asia: Bangladesh, India, Maldives, Sri Lanka. In: Proceedings of the Ninth International Coral Reef Symposium, Bali, 23-27 Oct 2000, pp. 841-845.

THOMPSON, P.M. and ISLAM, M.A. (Eds.). 2010. Environmental Profile of St. Martin's Island. United Nations Development Programme, Dhaka, 151 pp.

TOMASCIK, T., 1997. Management Plan for Resources of Narikel jinjira (St. Martin's Island) Final Report. National Conservation Strategy Implementation Project-1 Ministry of Environment and Forest, Government of Bangladesh, $125 \mathrm{pp}$. 
VERON, J.E.N. 1995. Corals in space and time: the biogeography and evolution of the Scleractinia. Univ. New South Wales Press, Sydney, Australia, 322 pp.

VERON, J.E.N. 2000. Corals of the World. Australian Institute of Marine Scince. Vol. 1-3, 1382 pp.

VERON, J.E.N., STAFFORD-SMITH, M.G., TURAK, E. and DEVANTIER, L.M. 2020. Corals of the World. Version 0.01(Beta). http://coralsoftheworld.org/v0.01 (Beta) on 20 September 2020.

WORMS EDITORIAL BOARD. 2020. World Register of Marine Species. Available from

http://www.marinespecies.org at VLIZ on 17 September 2020.

(Manuscript received on 26 October, 2020 revised on 30 April 2021) 